\title{
LINE X TESTER ANALYSIS FOR YIELD AND FIBER QUALITY IN COTTON (Gossypium hirsutum L.)
}

\author{
Aydin UNAY $Y^{*}$, Nedim OZBEK ${ }^{2}$, Volkan Mehmet CINAR ${ }^{3}$ \\ ${ }^{1}$ Aydın Adnan Menderes University, Faculty of Agriculture, Department of Field Crops, Aydın, TURKEY \\ ${ }^{2}$ Soke Oil Company, Soke-Aydin, TURKEY \\ ${ }^{3}$ Aydin Adnan Menderes University, Graduate School of Natural and Applied Sciences, Aydin, TURKEY \\ *Corresponding author: aunay@adu.edu.tr
}

Received: 11.02.2019

\begin{abstract}
This experiment was conducted in order to estimate gene action, combining ability and heterotic effects for yield and quality characters by the line $x$ tester analysis, involving 5 lines and 4 testers with 20 crosses in cotton (Gossypium hirsutum $\mathbf{L}$.). The ratio of general and specific ability variance revealed non-additive gene action effects for seed cotton yield, fiber length, fiber strength and ginning percentage and additive gene action for fiber fineness and reflectance degree. Claudia, Gloria and Bali 308 with high general combining ability were the best combiner parents and could be used for breeding multi-parent combinations. ST-468 x Claudia, Carisma x Carmen, Bali 308 x Gloria and Bali 308 x Claudia were promising combinations for further selection. Heterosis and heterobeltiosis values of most cross combinations for seed cotton yield, fiber strength and ginning percentage were negative direct. It was concluded that due to non-additive gene actions, it is advisable to select individual plants for seed cotton yield, ginning percentage and fiber traits in later generations $\left(\mathbf{F}_{\mathbf{4}}-\mathbf{F}_{\mathbf{6}}\right)$.
\end{abstract}

Key words: Combining ability, cotton, fiber quality, gene action, heterosis, yield

\section{INTRODUCTION}

The primary objectives of a cotton breeding are high yield and suitable fiber quality parameters. The information on heritability, combining ability and heterotic effects for yield and yield components, quality parameters directs to suitable parents and promising cross combination in a breeding programme. It was revealed that parents and cross combinations should be selected by their combining ability and gene action according to the efficacy of phenotypic performance. The line $\mathrm{x}$ tester analysis is one of the most important statistic-genetic methods which provides available knowledge about general and specific combining abilities of parents (GCA) and crosses (SCA) (Usharani et al., 2016). The number of evaluated genotypes using line $\mathrm{x}$ tester method is more than those of diallel analysis, scaling test etc.

The most important economic character, lint yield, is a product of seed cotton yield and ginning percentage. The color grade of cotton is determined by reflectance degree $(\mathrm{Rd})$ and yellowness $(+\mathrm{b})$, and reflectance degree indicates the more stable quantitative behavior than yellowness (Greveniotis et al., 2018). The ratio of $\sigma^{2} \mathrm{GCA} / \sigma^{2} \mathrm{SCA}$ could be useful in order to estimate the behavior of a segregating generation. Many researchers reported that seed cotton yield, fiber length, fiber strength and ginning percentage controlled by non-additive gene effect (Khokhar et al., 2018; Munir et al., 2018; Patil et al., 2018). Therefore, selection for improvement should be delayed to late generations $\left(\mathrm{F}_{4}-\mathrm{F}_{6}\right)$. Reflectance degree exhibited moderate heritability estimates (Amanu, 2018).

Heterosis is to estimate the performance of an $F_{1}$, produced by the crossing of two varieties or pure lines but the use of heterosis in cotton has not yet reached the successive level. In conventional breeding programmes, heterotic effects are used to determine the dominance or/and epistatic variance and the promising cross combinations. Zerihun et al. (2004), Lingaraja et al. (2017), Coban and Unay (2017) and Adsare et al. (2017) reported the moderately high and positive heterosis values for seed cotton yield whereas mostly low and negative values for ginning percentage and fiber quality parameters were determined by Dhamayanthi (2011).

The present study was aimed to evaluate gene action, combining ability and heterotic effects of yield and fiber quality characters in cotton consisting of five lines and four testers. Especially, there is little information on genetic-statistics parameters of reflectance degree of fiber. The parents use as the tester in our study, Claudia, Gloria, Julia and Carmen, are prominent cotton varieties in terms of reflectance degree of cotton fiber. 


\section{MATERIALS AND METHODS}

This research was conducted at the experimental area of Soke Oil Company, Aydin/Turkey during 2013 and 2014 growing years. The experimental material consists of five lines viz., Lider, ST-468, Carisma, Flash and Bali 308, and four testers; Gloria, Claudia, Julia and Carmen were crossed in line $\times$ tester mating design to produce twenty $F_{1}$ crosses. Parents and their crosses were grown in randomized complete block design with three replications. All the cultural managements such as plant density, sowing date, fertilization and irrigation were applied as recommended for the cotton growing of Aegean Region. Seed cotton yield (SCY; $\mathrm{kg} \mathrm{ha}^{-1}$ ), fiber fineness (FF; mic.), fiber length (FL; mm), fiber strength (FS; $\left.g_{\text {tex }}{ }^{-1}\right)$ and ginning percentage (GP; \%) and reflectance degree of fiber $(\mathrm{Rd})$ were recorded.

The variance analysis of line $\mathrm{x}$ tester suggested by Singh and Chaudhary (1979) were estimated using Microsoft Excel. Combining ability effects, heterosis and heterobeltiosis were computed for each characteristic. The critical values (CD) for the significance of the heterosis
(Ht) and heterobeltiosis ( $\mathrm{Hb}$ ) was tested by following standard errors.

$\mathrm{CD}$ for $\mathrm{Ht}$ at $5 \%$ and $1 \%=(3$ Mean square of error/ $2 \mathrm{r})^{1 / 2} \times \mathrm{t}_{(0.05)}$ and $\mathrm{t}_{(0.01)}$

$\mathrm{CD}$ for $\mathrm{Hb}$ at $5 \%$ and $1 \%=(2 \mathrm{Mean}$ square of error/ $\mathrm{r})^{1 / 2} \mathrm{x} \mathrm{t}_{(0.05)}$ and $\mathrm{t}_{(0.01)}$

\section{RESULTS AND DISCUSSION}

\section{Line $x$ Tester Analysis and ratios of $\sigma^{2} G C A / \sigma^{2} S C A$}

Analysis of variance showed that genotypic differences were significant for the characters (Table 1). Also, significant differences among parents and crosses indicated the presence of genetic diversity for all characters. The mean squares of parent versus crosses were significant for SCY, FF, FL and Rd. The differences between the overall mean of parents and their crosses indicate that crosses have advantages for FF, FL and Rd whereas parents have higher values for SCY. The interaction of line $\mathrm{x}$ tester was significant for all characteristics except FF.

Table 1. Analysis of variance for combining effects of different cotton characters.

\begin{tabular}{|c|c|c|c|c|c|c|c|c|c|c|c|c|c|}
\hline Source & df & SCY & & FF & & FL & & FS & & Rd & & GP & \\
\hline Replications & 2 & 2741.18 & & 0.03 & & 0.25 & & 0.90 & & 1.49 & & 0.07 & \\
\hline Genotypes & 29 & 31963.96 & $* *$ & 4.18 & $* *$ & 2.49 & $* *$ & 7.11 & $* *$ & 12.17 & $* *$ & 6.56 & $* *$ \\
\hline Parents & 8 & 34170.25 & $* *$ & 5.81 & $* *$ & 2.91 & $* *$ & 19.20 & $* *$ & 5.32 & $* *$ & 3.65 & $* *$ \\
\hline Crosses & 19 & 33352.03 & $* *$ & 2.76 & $* *$ & 2.15 & $* *$ & 2.63 & $* *$ & 12.65 & $* *$ & 8.48 & $* *$ \\
\hline $\mathrm{P}$ versus $\mathrm{C}$ & 1 & 19904.15 & $* *$ & 22.22 & $* *$ & 8.14 & $* *$ & 2.62 & & 70.09 & $* *$ & 0.05 & \\
\hline Lines & 4 & 61877.42 & $* *$ & 7.10 & $* *$ & 4.32 & $* *$ & 1.64 & & 43.11 & $* *$ & 4.92 & $* *$ \\
\hline Testers & 3 & 54905.75 & $* *$ & 3.04 & $* *$ & 2.85 & $* *$ & 3.46 & $* *$ & 4.19 & $* *$ & 17.00 & $* *$ \\
\hline Line $\mathrm{x}$ Tester & 12 & 18455.14 & $* *$ & 1.25 & & 1.25 & $* *$ & 2.76 & $* *$ & 4.61 & $* *$ & 7.64 & $* *$ \\
\hline Error & 58 & 3439.70 & & 0.43 & & 0.26 & & 1.19 & & 1.32 & & 0.28 & \\
\hline GCA/SCA & & 0.72 & & 1.79 & & 0.78 & & -0.18 & & 2.93 & & -0.09 & \\
\hline
\end{tabular}

$*, * * ;$ significant at $1 \%$ and $5 \%$ probability level, respectively.

High GCA to SCA variance ratio indicated preponderance of additive gene action. The additive gene actions for $\mathrm{FF}$ and $\mathrm{Rd}$; non-additive gene actions (dominant or epistasis) for SCY, FL, FS and GP were estimated. The variance ratio of GCA to SCA below 1 (0.72) indicates the role of non-additive gene action for the inheritance of SCY. Similar results were reported by Kaleem et al. (2016), Shakeel et al. (2016), Khokhar et al. (2018), Komala et al. (2018), Patil et al. (2018), Prakash et al. (2018) and Roy et al. (2018).

Also, non-additive gene effects for FL, FS and GP were predominant according to variance ratio of GCA to SCA with below 1. Our findings were in accordance with Khokhar et al. (2018); Munir et al. (2018); Patil et al. (2018). But Prakash et al. (2018) revealed that these characteristics were controlled by additive gene effects.

In our study, variance ratio values of GCA to SCA for FF and Rd were determined as 1.79 and 2.93, respectively. It was shown that FF and Rd were managed largely by additive gene effects. Our results were similar to Prakash et al. (2018) but Munir et al. (2018) and Patil et al. (2018) were found non-additive gene effects for FF. This contradiction may be due to genotypic material and different mating design.

\section{GCA and SCA effects}

Significant GCA effects were detected for yield components, SCY and all fiber quality characteristics (Table 2). Among the parents Bali 308, Claudia and Carmen exhibited significant positive GCA effects for SCY. However, Lider, ST-468 and Julia were significant negative GCA effects for SCY. For FF, Lider would be promising to develop thinner fiber progenies. GCA effects of other parents and SCA effects of all crosses were nonsignificant in terms of FF. Bali 308, Flash and Carmen with positive and significant GCA effects contributed to the increase in FL in their combinations which crossed with. Carmen was the best combiner for FS because of its significant and positive GCA effects. Bali 308, Flash and Gloria for Rd; Claudia and ST-468 for GP had significant and positive GCA effects. 
Table 2. GCA and SCA effects of observed characters.

\begin{tabular}{|c|c|c|c|c|c|c|}
\hline & SCY & FF & FL & FS & Rd & GP \\
\hline \multicolumn{7}{|l|}{ Lines } \\
\hline Lider & $-53.75 * *$ & $-0.35^{*}$ & $-0.40 * *$ & -0.16 & $-0.60 *$ & $-0.78 * *$ \\
\hline ST-468 & $-54.75^{* *}$ & 0.08 & $-0.31 * *$ & 0.25 & $-2.13 * *$ & $0.26 *$ \\
\hline Carisma & -9.42 & 0.24 & $-0.56 * *$ & 0.50 & $-1.12 * *$ & $0.83 * *$ \\
\hline Flash & -3.08 & 0.18 & $0.42 * *$ & -0.15 & $1.29 * *$ & 0.17 \\
\hline Bali 308 & $121.00 * *$ & -0.15 & $0.84 * *$ & -0.16 & $2.56 * *$ & $-0.50 * *$ \\
\hline \multicolumn{7}{|l|}{ Tester } \\
\hline Gloria & 24.72 & -0.11 & 0.02 & -0.43 & $0.50 *$ & $-0.31 * *$ \\
\hline Claudia & $34.32 *$ & 0.19 & 0.17 & 0.05 & 0.05 & $1.55^{* *}$ \\
\hline Julia & $-90.55^{* *}$ & -0.11 & $-0.61 * *$ & -0.27 & $-0.74 * *$ & $-0.76 * *$ \\
\hline Carmen & $31.52 *$ & 0.03 & $0.42 * *$ & $0.65 *$ & 0.19 & $-0.48 * *$ \\
\hline \multicolumn{7}{|l|}{ Crosses } \\
\hline Lider x Gloria & $129.28 * *$ & 0.22 & 0.01 & -0.52 & $2.84 * *$ & -0.31 \\
\hline Lider x Claudia & $-82.32 * *$ & 0.16 & 0.25 & -0.27 & $-1.24 *$ & 0.46 \\
\hline Lider x Julia & $-65.78 *$ & -0.41 & -0.38 & -0.78 & -0.38 & $0.57 *$ \\
\hline Lider x Carmen & 18.82 & 0.03 & 0.12 & $1.56 * *$ & $-1.22 *$ & $-0.71 * *$ \\
\hline ST-468 x Gloria & -55.05 & -0.14 & $-0.57 *$ & -0.86 & -0.86 & -0.30 \\
\hline ST-468 x Claudia & $71.02 *$ & 0.19 & 0.38 & 0.66 & 0.99 & $0.74 * *$ \\
\hline ST-468 x Julia & -1.78 & 0.09 & 0.16 & 0.55 & -1.05 & 0.09 \\
\hline ST-468 x Carmen & -14.18 & -0.14 & 0.03 & -0.35 & 0.92 & $-0.53 *$ \\
\hline Carisma x Gloria & -42.38 & -0.07 & -0.39 & -0.47 & -0.60 & $1.29 * *$ \\
\hline Carisma x Claudia & $86.35 * *$ & -0.28 & $-0.65^{*}$ & -0.52 & -0.35 & $-3.61 * *$ \\
\hline Carisma x Julia & $-70.78 *$ & 0.26 & -0.15 & 0.47 & 0.38 & $-0.53 *$ \\
\hline Carisma x Carmen & 26.82 & 0.08 & $1.19 * *$ & 0.51 & 0.58 & $2.86 * *$ \\
\hline Flash x Gloria & $-60.72 *$ & 0.05 & $0.62 *$ & 0.35 & $-1.21 *$ & 0.14 \\
\hline Flash x Claudia & -29.65 & -0.07 & 0.42 & 0.83 & 0.37 & $0.81 * *$ \\
\hline Flash x Julia & $117.22 * *$ & 0.03 & 0.10 & -0.24 & 0.90 & 0.05 \\
\hline Flash x Carmen & -26.85 & -0.02 & $-1.15 * *$ & -0.94 & -0.07 & $-1.00 * *$ \\
\hline Bali 308 x Gloria & 28.87 & -0.06 & 0.32 & $1.49 * *$ & -0.18 & $-0.82 * *$ \\
\hline Bali 308 x Claudia & -45.40 & -0.01 & -0.40 & -0.70 & 0.23 & $1.61 * *$ \\
\hline Bali 308 x Julia & 21.13 & 0.02 & 0.27 & -0.01 & 0.16 & -0.17 \\
\hline Bali 308 x Carmen & -4.60 & 0.05 & -0.19 & -0.80 & -0.21 & $-0.62 *$ \\
\hline
\end{tabular}

*, $* * ;$ significant at $1 \%$ and $5 \%$ probability level, respectively.

The SCA effects revealed that the best specific combinations were Lider x Gloria, Flash x Julia, Carisma $\mathrm{x}$ Claudia and ST-468 x Claudia for SCY; Carisma $\mathrm{x}$ Carmen for FL; Lider x Carmen and Bali 308 x Gloria for FS; Lider x Gloria for Rd; Carisma x Carmen, Bali 308 x Claudia and Carisma x Gloria, Flash x Claudia and Lider $\mathrm{x}$ Julia for GP (Table 2).

\section{Mean performance of $F_{1}$ crosses and parental cultivars}

There was a significant change in the performance of the parents for each character (Table 3). The range of SCY was between $302.67 \mathrm{~kg} \mathrm{da}^{-1}$ (Flash) and $649.67 \mathrm{~kg} \mathrm{da}^{-1}$ (Claudia). Lider was the highest FF value (5.43) whereas Gloria gave the lowest FF value (4.18). The longest fiber $(31.13 \mathrm{~mm})$ was calculated for Claudia, while Bali 308 was the shortest FL of $27.74 \mathrm{~mm}$. Among parents, FS varied from $34.7 \mathrm{~g} \mathrm{tex}^{-1}$ (Gloria) to $28.3 \mathrm{~g} \mathrm{tex}^{-1}$ (Carisma). Also, among the lines and testers, the highest and lowest GP were obtained for Claudia (45.37\%) and Bali 308 $(41.90 \%)$. In the case of $\mathrm{Rd}$, the lowest (73.70) and the highest (78.37) values were produced by ST-468 and Gloria, respectively. The mean of lines and tester were 75.1 and 76.8 for $\mathrm{Rd}$, respectively.

The crosses differenced dramatically for each trait (Table 3). The mean SCY ranged between $241.00 \mathrm{~kg} \mathrm{da}^{-1}$ (Lider x Julia) and $625.67 \mathrm{~kg} \mathrm{da}^{-1}$ (Bali $308 \times$ Gloria). ST$468 \times$ Claudia revealed the highest FF value (5.00 mic.) whereas revealed the lowest FF value $(3.68$ mic.) was obtained for Lider x Julia. Bali 308 x Gloria was the longest fibers $(30.50 \mathrm{~mm})$ while Lider $\mathrm{x}$ Julia gave the shortest FL of $28.06 \mathrm{~mm}$. Among combinations, Lider x Carmen had the strongest fibers $\left(34.50 \mathrm{~g} \mathrm{tex}^{-1}\right)$ and Lider $\mathrm{x}$ Julia had the weakest fibers $\left(30.70 \mathrm{~g} \mathrm{tex}^{-1}\right)$. Also, among the hybrids Carisma x Carmen had the highest GP (46.50 $\%$ ) and Lider x Carmen had the lowest GP (41.33\%). In case of $\mathrm{Rd}$, the highest (77.25) and the lowest (74.75) values were produced by Carisma x Gloria and ST-468 x Carmen, respectively. The mean of crosses (76.05) shown that $F_{1}$ population had higher values in a positive direction. 
Table 3. Mean values of observed characters.

\begin{tabular}{|c|c|c|c|c|c|c|}
\hline & SCY & FF & FL & FS & Rd & GP \\
\hline \multicolumn{7}{|l|}{ Lines } \\
\hline Lider & 452.00 & 5.43 & 28.73 & 31.23 & 75.27 & 44.23 \\
\hline ST-468 & 519.67 & 4.83 & 28.67 & 34.07 & 73.70 & 43.20 \\
\hline Carisma & 522.00 & 5.40 & 27.93 & 28.37 & 76.13 & 44.43 \\
\hline Flash & 302.67 & 5.34 & 28.90 & 31.80 & 75.03 & 42.93 \\
\hline Bali 308 & 408.33 & 4.75 & 27.74 & 28.73 & 75.53 & 41.90 \\
\hline \multicolumn{7}{|l|}{ Tester } \\
\hline Gloria & 607.67 & 4.18 & 29.11 & 34.70 & 78.37 & 42.87 \\
\hline Claudia & 649.67 & 4.95 & 31.13 & 34.47 & 77.10 & 45.37 \\
\hline Julia & 406.33 & 4.44 & 28.39 & 34.53 & 76.60 & 42.83 \\
\hline Carmen & 485.67 & 4.65 & 28.42 & 34.10 & 75.80 & 42.40 \\
\hline Mean $_{\text {(Parents) }}$ & 483,77 & 4,89 & 28,78 & 32,44 & 75,94 & 43,35 \\
\hline \multicolumn{7}{|l|}{ Crosses } \\
\hline Lider x Gloria & 551.33 & 4.30 & 29.08 & 32.30 & 76.82 & 41.90 \\
\hline Lider x Claudia & 349.33 & 4.55 & 29.47 & 32.50 & 76.18 & 44.53 \\
\hline Lider x Julia & 241.00 & 3.68 & 28.06 & 30.70 & 75.93 & 42.33 \\
\hline Lider x Carmen & 447.67 & 4.25 & 29.58 & 34.50 & 75.53 & 41.33 \\
\hline ST-468 x Gloria & 366.00 & 4.36 & 28.59 & 31.37 & 76.03 & 42.97 \\
\hline ST-468 x Claudia & 501.67 & 5.00 & 29.65 & 33.37 & 75.40 & 45.87 \\
\hline ST-468 x Julia & 304.00 & 4.60 & 28.69 & 32.93 & 75.15 & 42.90 \\
\hline ST-468 x Carmen & 413.67 & 4.50 & 29.57 & 32.97 & 74.75 & 42.57 \\
\hline Carisma x Gloria & 424.00 & 4.60 & 28.52 & 32.17 & 77.25 & 45.10 \\
\hline Carisma x Claudia & 562.33 & 4.70 & 28.40 & 32.60 & 76.62 & 42.07 \\
\hline Carisma x Julia & 280.33 & 4.94 & 28.13 & 33.27 & 76.37 & 42.83 \\
\hline Carisma x Carmen & 500.00 & 4.89 & 30.49 & 34.23 & 75.97 & 46.50 \\
\hline Flash x Gloria & 412.00 & 4.66 & 30.50 & 33.23 & 76.70 & 43.30 \\
\hline Flash x Claudia & 452.67 & 4.84 & 30.46 & 34.20 & 76.07 & 45.83 \\
\hline Flash x Julia & 474.67 & 4.65 & 29.35 & 32.80 & 75.82 & 42.77 \\
\hline Flash x Carmen & 452.67 & 4.72 & 29.13 & 33.03 & 75.42 & 42.00 \\
\hline Bali 308 x Gloria & 625.67 & 4.22 & 30.62 & 33.73 & 76.95 & 41.67 \\
\hline Bali 308 x Claudia & 561.00 & 4.58 & 30.05 & 32.03 & 76.32 & 45.97 \\
\hline Bali 308 x Julia & 502.67 & 4.31 & 29.94 & 32.40 & 76.07 & 41.87 \\
\hline Bali 308 x Carmen & 599.00 & 4.47 & 30.50 & 32.53 & 75.67 & 41.70 \\
\hline Mean $_{\text {(crosses) }}$ & 451,08 & 4,54 & 29,51 & 32,84 & 76,05 & 43,30 \\
\hline $\operatorname{LSD}_{(0.05)}$ & 79.40 & 0.88 & 0.69 & 0.49 & 1.56 & 0.72 \\
\hline
\end{tabular}

\section{Heterotic Effects}

Heterosis estimates of crosses combinations are presented in Table 4. Heterosis values for SCY ranged from $34 \%$ (Bali $308 \times$ Carmen) to $-43.84 \%$ (Lider x Julia). Bali 308 x Carmen, Flash x Julia, Bali 308 x Julia and Bali 308 x Gloria were significant and positive heterosis. Among the $F_{1}$ crosses, the significantly but negative heterosis was estimated $-25.50 \%$ (Lider $\times$ Julia) and $15.58 \%$ (Lider x Carmen) for FF.

For FL, heterosis values were between -3.83 to $8.63 \%$ for the crosses. Bali $308 \times$ Carmen, Carisma x Carmen, Bali 308 x Gloria, Bali 308 x Julia, Flash x Gloria, ST-468 $\mathrm{x}$ Carmen and Lider $\mathrm{x}$ Carmen combinations showed significant and positive heterosis. Regarding FS, the significant and positive heterosis values were estimated for Carisma x Carmen (9.61 \%), Bali 308 x Gloria and Lider x Carmen combinations. Although, Bali 308 x
Carmen (6.30) were the highest significant positive heterosis Lider x Julia (-59.57) exhibited the lowest significant negative heterosis for Rd. The most significant positive and negative heterosis values for GP were found for Carisma x Carmen $(7.10 \%)$ and Carisma x Claudia ($6.31 \%$ ) combinations.

Heterobeltiosis estimates of hybrids were varied significantly for each character (Table 5). The values of heterobeltiosis ranged between $-46.68 \%$ (Lider x Julia) and $23.33 \%$ (Bali $308 \times$ Carmen) for SCY; $-17.19 \%$ (Lider x Carmen) and $11.40 \%$ (Flash x Gloria) for FF; $8.76 \%$ (Carisma x Claudia) to $7.32 \%$ (Bali $308 \times$ Carmen) for FL; -7.28 \% (Carisma x Claudia) and $4.66 \%$ (Carisma x Carmen) for GP; -11.09 \% (Lider x Julia) and $1.17 \%$ (Lider x Carmen) for FS; -59.92 (Lider x Julia) and $6.11 \%$ (Bali $308 \times$ Carmen) for Rd. Unlike, no significant the value of heterobeltiosis for the crosses was estimated for FF. 
Table 4. Heterosis values of observed characters

\begin{tabular}{|c|c|c|c|c|c|c|}
\hline & SCY & FF & FL & FS & Rd & GP \\
\hline Lider x Gloria & 4.06 & -10.55 & 0.54 & -2.02 & $-57.95 * *$ & $-3.79 * *$ \\
\hline Lider x Claudia & $-36.58 * *$ & -12.42 & -1.54 & -1.07 & $-57.34 * *$ & -0.60 \\
\hline Lider x Julia & $-43.84 * *$ & $-25.50 * *$ & -1.77 & $-6.64 * *$ & $-59.57 * *$ & $-2.76 * *$ \\
\hline Lider x Carmen & -4.51 & $-15.58 *$ & $3.52 * *$ & $5.61 * *$ & $-54.32 * *$ & $-4.58 * *$ \\
\hline ST-468 x Gloria & $-35.07 * *$ & -3.14 & -1.03 & $-8.77 * *$ & -0.83 & -0.15 \\
\hline ST-468 x Claudia & $-14.20 *$ & 2.11 & -0.84 & -2.63 & $1.86^{*}$ & $3.58 * *$ \\
\hline ST-468 x Julia & $-34.34 * *$ & -0.79 & 0.56 & $-3.98 *$ & -1.57 & -0.27 \\
\hline ST-468 x Carmen & $-17.71 *$ & -4.99 & $3.61 * *$ & -3.28 & $2.83 * *$ & -0.55 \\
\hline Carisma x Gloria & $-24.93 * *$ & -3.86 & -0.02 & 2.01 & -0.76 & $3.32 * *$ \\
\hline Carisma x Claudia & -4.01 & -9.27 & $-3.83 * *$ & 3.77 & -0.20 & $-6.31 * *$ \\
\hline Carisma x Julia & $-39.61 * *$ & 0.41 & -0.13 & $5.78 *$ & 0.04 & $-1.83^{*}$ \\
\hline Carisma x Carmen & -0.76 & -2.65 & $8.23 * *$ & $9.61 * *$ & $2.06^{*}$ & $7.10 * *$ \\
\hline Flash x Gloria & -9.48 & -2.14 & $5.17 * *$ & -0.05 & $2.30 *$ & 0.93 \\
\hline Flash x Claudia & -4.94 & -6.02 & 1.47 & 3.22 & $4.65 * *$ & $3.81 * *$ \\
\hline Flash x Julia & $33.90 * *$ & -4.98 & $2.47 *$ & -1.11 & $4.64 * *$ & -0.27 \\
\hline Flash x Carmen & 14.84 & -5.41 & 1.65 & 0.25 & $5.15^{* *}$ & $-1.56^{*}$ \\
\hline Bali 308 x Gloria & $23.16 * *$ & -5.41 & $7.74 * *$ & $6.36^{* *}$ & $4.96 * *$ & $-1.69 *$ \\
\hline Bali 308 x Claudia & 6.05 & -5.63 & $2.10 *$ & 1.37 & $5.79 * *$ & $5.35^{* *}$ \\
\hline Bali 308 x Julia & $23.40 *$ & -6.24 & $6.68 * *$ & 2.42 & $5.00 * *$ & -1.18 \\
\hline Bali 308 x Carmen & $34.00 * *$ & -4.96 & $8.63 * *$ & 3.55 & $6.30 * *$ & -1.07 \\
\hline
\end{tabular}

Table 5. Heterobeltiosis values of observed characters

\begin{tabular}{|c|c|c|c|c|c|c|}
\hline & SCY & FF & FL & FS & Rd & GP \\
\hline Lider x Gloria & -9.27 & 2.79 & -0.11 & $-6.92 * *$ & $-58.79 * *$ & $-5.27 * *$ \\
\hline Lider x Claudia & $-46.23 * *$ & -8.15 & $-5.33 * *$ & $-5.72 *$ & $-57.85 * *$ & $-1.84 * *$ \\
\hline Lider x Julia & $-46.68 * *$ & -17.19 & -1.17 & $-11.09 * *$ & $-59.92 * *$ & $-4.29 * *$ \\
\hline Lider x Carmen & -7.82 & -8.53 & $4.08 * *$ & 1.17 & $-54.49 * *$ & $-6.55 * *$ \\
\hline ST-468 x Gloria & $-39.77 * *$ & 4.39 & -1.79 & $-9.61 * *$ & $-3.79 * *$ & -0.54 \\
\hline ST-468 x Claudia & $-22.78 * *$ & 3.45 & $-4.78 * *$ & -3.20 & -0.39 & $1.09 * *$ \\
\hline ST-468 x Julia & $-41.50 * *$ & 3.60 & 0.17 & $-4.62 *$ & $-3.44 * *$ & $-0.69 *$ \\
\hline ST-468 x Carmen & $-20.40 *$ & -3.15 & $3.15^{*}$ & -3.32 & 1.41 & $-1.47 * *$ \\
\hline Carisma x Gloria & $-30.23 * *$ & 10.13 & -2.04 & $-7.30 * *$ & $-2.17 *$ & $1.51 * *$ \\
\hline Carisma x Claudia & $-13.44 *$ & -5.12 & $-8.76 * *$ & $-5.43 *$ & -0.82 & $-7.28 * *$ \\
\hline Carisma x Julia & $-46.30 * *$ & 11.26 & -0.93 & -3.66 & -0.26 & $-3.59 * *$ \\
\hline Carisma x Carmen & -4.21 & 5.16 & $7.30 * *$ & 0.39 & 1.84 & $4.66 * *$ \\
\hline Flash x Gloria & $-32.20 * *$ & 11.40 & $4.79 * *$ & $-4.23 *$ & 0.12 & $0.86^{*}$ \\
\hline Flash x Claudia & $-30.32 * *$ & -2.29 & $-2.16^{*}$ & -0.78 & $3.24 * *$ & $1.02 * *$ \\
\hline Flash x Julia & 16.82 & -12.98 & 1.57 & $-5.01 *$ & $3.57 * *$ & -0.38 \\
\hline Flash x Carmen & -6.80 & 1.58 & 0.80 & -3.13 & $4.62 * *$ & $-2.17 * *$ \\
\hline Bali 308 x Gloria & 2.96 & 1.04 & $5.20 * *$ & -2.79 & $3.06 * *$ & $-2.81 * *$ \\
\hline Bali 308 x Claudia & $-13.65^{*}$ & -7.54 & $-3.46 * *$ & $-7.07 * *$ & $4.71 * *$ & $1.32 * *$ \\
\hline Bali 308 x Julia & $23.10^{*}$ & -2.93 & $5.46^{* *}$ & $-6.17 * *$ & $4.26 * *$ & $-2.25 * *$ \\
\hline Bali 308 x Carmen & $23.33^{*}$ & -3.94 & $7.32 * *$ & $-4.59 *$ & $6.11 * *$ & $-1.65 * *$ \\
\hline
\end{tabular}

$*, * *$; significant at $1 \%$ and $5 \%$ probability level, respectively.

It was determined that heterotic effects for SCY, FS and GP were mostly negative direction whereas numerous cross combinations showed positive heterosis and heterobeltiosis for FF, FL and Rd. Our results are similar to the findings of Solanki et al. (2014) and Khokhar et al. (2018).

\section{CONCLUSION}

The non-additive gene effects were predominant for seed cotton yield, fiber length, fiber strength and ginning percentage. Cultivar Claudia was the most suitable parent to combine crossing blocks for all traits. Also, Gloria and Bali 308 were good combiners for seed cotton yield but the cross combinations of these parents should be crossed with a combined with high GCA effects in terms of ginning percentage and fiber traits. The hybrids ST-468 x Claudia, Carisma x Carmen, Bali 308 x Gloria and Bali $308 \times$ Claudia were the most promising for improving the yield and fiber traits. Moreover, out of four, two crosses viz., Bali 308 x Gloria and Bali 308 x Claudia involved both the parents have GCA effect for seed cotton yield. Higher heterosis and heterobeltiosis for SCY were 
observed whereas mostly lower values for fiber traits and ginning percentage were estimated. It was concluded that due to non-additive gene actions, it is advisable to select individual plants for seed cotton yield, ginning percentage and fiber properties in later generations $\left(\mathrm{F}_{4}-\mathrm{F}_{6}\right)$.

\section{LITERATURE CITED}

Adsare, A.D., A.N. Salve and N.P. Patil. 2017. Heterosis studies for quantitative traits in interspecific hybrids of cotton (Gossypium hirsutum L. x Gossypium barbadense L.). J. of Phyto. 9: 11-14.

Amanu W. 2018. Genetic variability and heritability studies of seed cotton yield and fiber quality in F5 segregating generations of upland cotton (Gossypium hirsutum L.). Ph. D. Dissertation. The University of Hawassa, p. 55.

Coban, M. and A. Unay. 2017. Gene action and useful heterosis in interspecific cotton crosses (Gossypium hirsutum L. $\mathrm{x}$ Gossypium barbadense L.). J. of Agri. Sci. 23: 438-443.

Dhamayanthi, K.P.M. 2011. Study of interspecific hybrids (Gossypium hirsutum $x$ G. Barbadense L.) for heterosis and combining ability. World Cott. Res. Conf.-5., Mumbai, India. 51-55.

Greveniotis, V., E. Sioki and C.G. Ipsilandis. 2018. Estimations of fibre trait stability and type of inheritance in cotton. Czech J. of Genet. and Plant Breed. 54: 190-192.

Kaleem, M.N., I.A. Rana, A. Shakeel, L. Hinze, R.A. Atif and M.T. Azhar. 2016. Genetic analysis of some agronomic and fiber traits in Gossypium hirsutum L. grown in field conditions. Turk. J. of Field Crops. 21(2): 240-245.

Khokhar, E.S., A. Shakeel, M.A. Maqbool, M.K. Abuzar, S. Zareen, S.S. Aamir and M. Asadullah. 2018. Studying combining ability and heterosis in different cotton (Gossypium hirsutum L.) genotypes for yield and yield contributing traits. Pak. J. of Agri. Res. 31:55-68.

Lingaraja, L., R.S. Sangwan, S. Nimbal, O. Sangwan and S. Singh. 2017. Heterosis studies for economic and fiber quality traits in line $\mathrm{x}$ tester crosses of uplan cotton (Gossypium hirsutum L.). Int. J. of Pure \& App. Bio. Sci. 5: 240-248.

Komala M., N.M. Ganesan and M. Kumar. 2018. Combining ability for yield and yield contributing traits in intraspecific hybrids of ratoon upland cotton. Int. J. of Bas. and App. Agri. Res. 16: 22-28.

Munir, S., M.K. Qureshi, A.N. Shahzad, H. Manzoor, M.A. Shahzad, K. Aslam and H.U.R. Athar. 2018. Assessment of gene action and combining ability for fibre and yield contributing traits in interspecific and intraspecific hybrids of cotton. Czech J. of Genet. and Plant Breed. 54: 71-77.

Patil, A.E., D.B. Deosarkar and M.R. Puttawar. 2018. Environmental impact on the stability of gene action for seed cotton yield in Cotton (Gossypium hirsutum L.). Int. J. of Curr. Microbiol. App. Sci. 7: 1319-1329.

Prakash, G., S.L. Korekar and S. Mankare. 2018. Combining ability analysis in bt cotton (Gossypium hirsutum L.) to harness high yield under contrasting planting densities through heterosis breeding. Int. J. of Curr. Microbiol. App. Sci. 7: 1765-1774.

Shakeel, A., M.M. Sheraz, A. Saeed, I. Ali, W. Nazeer, Z. Amin and A. Ammar. 2016. Estimation of combining ability and heterotic potential for within-boll yield traits under leaf curling disease infestation in cotton. Turk. J. of Field Crops. 20: 44-50.

Singh, R.K. and B.D. Chaudhary. 1979. Line x Tester Analysis. In: Biometrical Methods in Quantiative Genetic Analysis. New Delhi. Kalyani Publ. Company. 205-214.

Solanki, H.V., D.R. Mehta, V.B. Rathodand and M.G. Valu. 2014. Heterosis for seed cotton yield and its contributing characters in cotton (Gossypium hirsutum L.). Electr. J. Plant Breed. 5:124-130.

Usharani, C.V., S.M. Manjula and S.S. Patil. 2016. Estimating combining ability through Line $\times$ Tester analysis in upland cotton. Res. in Environ. and Life Sci. 9: 628-633.

Roy, U., M.C. Paloti, R.S. Patil and I.S. Katageri. 2018. Combining ability analysis for yield and yield attributing traits in interspecific (Gossypium hirsutum L. $\times$ Gossypium barbadense L.) hybrids of cotton. Electr. J. of Plant Breed. 9: 458-464.

Zerihun D., N. Ratanadilok, R. Kaveeta, P. Pongtongkam and A. Kuantham. 2004. Heterosis and combining ability for yield and yield components of cotton (Gossypium hirsutum L.). J. of Nat. Sci. 38: 11-20. 